\title{
PQQ-Dependent Production of Gluconic Acid by Acinetobacter, Agrobacterium and Rhizobium Species
}

\author{
By B. J. VAN SCHIE, ${ }^{\dagger} \dagger$ O. H. DE MOOY ${ }^{1}$, J. D. LINTON ${ }^{2}$, \\ J. P. VAN DIJKEN ${ }^{1 *}$ AND J. G. KUENEN ${ }^{1}$ \\ ${ }^{1}$ Laboratory of Microbiology, Delft University of Technology, Delft, The Netherlands \\ ${ }^{2}$ Shell Research Laboratories, Sittingbourne, Kent ME9 8AG, UK
}

(Received 9 June 1986; revised 15 September 1986)

\begin{abstract}
Acinetobacter lwoffi, Azotobacter vinelandii, Agrobacterium and Rhizobium species contain quinoprotein glucose dehydrogenase apoenzyme (EC 1.1.99.17). Addition to whole cells of pyrrolo-quinoline quinone (PQQ), the prosthetic group of this enzyme, resulted in the production of gluconic acid from glucose. The in vivo reconstitution of apo-glucose dehydrogenase with PQQ was dependent on the presence of $\mathrm{Ca}^{2+}$ or $\mathrm{Mg}^{2+}$. Optimal conditions for reconstitution allowed maximal glucose dehydrogenase activity in the presence of 1-10 nmol PQQ $1^{-1}$. Synthesis of the apoenzyme of glucose dehydrogenase was not dependent on glucose in the growth media. The physiological significance of the synthesis of apo-glucose dehydrogenase, as found in a variety of bacteria, is discussed.
\end{abstract}

\section{INTRODUCTION}

The bacterial metabolism of sugars may proceed via different catabolic routes. Differences in sugar metabolism may also be found in the mode of entrance of sugars into these routes. For example in Escherichia coli phosphorylation is the first step in aldose metabolism whereas Pseudomonas spp. can catalyse the initial oxidation of the phosphorylated or nonphosphorylated sugar to the corresponding (phosphorylated) aldonic acid, which may transiently accumulate in the medium. The importance of the direct oxidation pathway relative to the phosphorylative route has been intensively studied (Dawes, 1981; Lessie \& Phibbs, 1984). In Pseudomonas spp. the direct oxidation pathway is obligatory for growth on aldopentoses (Doelle, 1975) but during growth on aldohexoses this route may be bypassed depending on environmental conditions (Lessie \& Phibbs, 1984).

In all cases examined so far the accumulation of aldonic acids by bacteria is associated with the presence of a membrane-bound aldose dehydrogenase (known as 'glucose dehydrogenase', $\mathrm{GDH})$ which contains pyrrolo-quinoline quinone (PQQ) as a prosthetic group (Duine et al., 1979). The enzyme is probably located on the periplasmic side of the cell membrane (Dawes, 1981) and donates its electrons to the electron transport chain at the level of cytochrome $b$ (Hauge, 1960; Beardmore-Gray \& Anthony, 1986). A peculiar example of GDH synthesis in bacteria can be found in Acinetobacter calcoaceticus, most strains of which can oxidize glucose to gluconic acid but do not grow at all on either of the two compounds (Juni, 1978).

Bacteria unable to oxidize glucose to gluconic acid are not necessarily devoid of GDH protein. We have recently shown that Acinetobacter $/$ woffi constitutively synthesizes apo-GDH which can be reconstituted to active enzyme upon addition of nanomolar quantities of PQQ (van Schie et al., 1984). As a result, PQQ supplemented cultures of $A c$. Iwoffi can oxidize glucose instantaneously to gluconic acid at a rate similar to that of $A c$. calcoaceticus (van Schie et al., 1984). Like $A c$. lwoff, various $E$. coli strains also contain apo-GDH (Hommes et al., 1984; van

† Present address: Unilever Research Laboratory, PO Box 114, 3130 AC, Vlaardingen, The Netherlands.

Abbreviations: GDH, glucose dehydrogenase; PQQ, pyrrolo-quinoline quinone; PES, phenazine ethosulphate. 
Schie et al., 1985), the synthesis of which is constitutive. Existence of the synthesis of nonfunctional apo-enzyme is not restricted to glucose dehydrogenase; PQQ-dependent alcohol dehydrogenase (Groen et al., 1986) and polyvinyl alcohol dehydrogenase (Shimao et al., 1986) were reported recently to exist as apo-enzymes.

Glucose appeared to be a very effective energy source for driving secondary solute transport in PQQ preincubated membrane vesicles of $E$. coli (van Schie et al., 1985) and in membrane vesicles of Ac. calcoaceticus (Pronk et al., 1986). This establishes a role for GDH in energy metabolism in these bacteria.

In view of the phenomena discussed above the following questions are considered in this paper. (1) Are bacteria which produce apo-GDH auxotrophic for PQQ, or is the synthesis of this cofactor dependent on environmental conditions in these organisms? (2) Is the synthesis of apo-GDH a widespread phenomenon?

\section{METHODS}

Organisms. The following strains were obtained from the Laboratory of Microbiology Delft culture collection: Acinetobacter calcoaceticus LMD 79.41, Acinetobacter Iwoffi LMD 73.1, Escherichia coli B/r/l. Agrobacterium tumefaciens C58 (see Zambryski et al., 1983), Agrobacterium radiobacter NCIB 11883, Pseudomonas sp. NCIB 49592, Xanthomonas campestris pathovars - begoniae (NCPPB 2266), hyacinthii (NCPPB 599), juglandis (NCPPB 411), nakataecorchori (NCPPB 1337) and phaseoli (NCPPB 1811) - and Xanthomonas campestris NCIB 11803 were obtained from Shell Research Laboratories, Sittingbourne. Agrobacterium tumefaciens LBA 201 was provided by Dr P.J.J. Hooykaas, and Rhizobium leguminosarum 248, R. leguminosarum biovar trifolii LPR 5001 and Rhizobium meliloti 1126 were a gift from Dr C. Wijffelman (both of the Department of Plant Molecular Biology, State University of Leiden, The Netherlands).

Growth media and culture conditions. The Acinetobacter strains and Ag. tumefaciens LBA 201 were grown in an acetate- $\left(30 \mathrm{mmol}^{-1}\right)$ or glycerol- $\left(15 \mathrm{mmol}^{-1}\right)$ limited continuous culture as described previously (van Schie $e t$ al., 1984). The mineral salts medium contained, per litre: $\left(\mathrm{NH}_{4}\right)_{2} \mathrm{SO}_{4}, 4.0 \mathrm{~g} ; \mathrm{K}_{2} \mathrm{HPO}_{4}, 1.4 \mathrm{~g} ; \mathrm{KH}_{2} \mathrm{PO}_{4}, 0.8 \mathrm{~g}$; $\mathrm{MgSO}_{4} .7 \mathrm{H}_{2} \mathrm{O}, 0.2 \mathrm{~g}$; EDTA, $15 \mathrm{mg} ; \mathrm{ZnSO}_{4} .7 \mathrm{H}_{2} \mathrm{O}, 4.5 \mathrm{mg} ; \mathrm{CoCl}_{2} .6 \mathrm{H}_{2} \mathrm{O}, 0.3 \mathrm{mg} ; \mathrm{MnCl}_{2} .4 \mathrm{H}_{2} \mathrm{O}, 1 \mathrm{mg}$; $\mathrm{CuSO}_{4} .5 \mathrm{H}_{2} \mathrm{O}, 0.3 \mathrm{mg} ; \mathrm{CaCl}_{2} .2 \mathrm{H}_{2} \mathrm{O}, 4.5 \mathrm{mg} ; \mathrm{FeSO}_{4} .7 \mathrm{H}_{2} \mathrm{O}, 3 \mathrm{mg} ; \mathrm{NaMoO}_{4} .2 \mathrm{H}_{2} \mathrm{O}, 0.04 \mathrm{mg} ; \mathrm{H}_{3} \mathrm{BO}_{3}, 1 \mathrm{mg} ; \mathrm{KI}$, $0.1 \mathrm{mg}$. R. leguminosarum 248 was grown in batch cultures on glucose $\left(10 \mathrm{~g} \mathrm{I}^{-1}\right)$ or grown in a glucose-limited continuous culture on a mineral medium (de Vries, 1980).

During continuous cultivation, dissolved oxygen was measured with a galvanic oxygen electrode, and controlled at the desired value by the stirring rate. Cultures were sparged with mixtures of air and pure oxygen to obtain partial oxygen pressures above air saturation.

The Xanthomonas strains, Ag. tumefaciens C58, Ag. radiobacter and Pseudomonas sp. were grown in batch cultures on a mineral medium containing, per litre: glucose $10.0 \mathrm{~g} ;\left(\mathrm{NH}_{4}\right)_{2} \mathrm{SO}_{4}, 3.0 \mathrm{~g} ; \mathrm{Na}_{2} \mathrm{HPO}_{4}, 3.0 \mathrm{~g} ; \mathrm{KH}_{2} \mathrm{PO}_{4}$, $3.0 \mathrm{~g} ; \mathrm{MgSO}_{4} .7 \mathrm{H}_{2} \mathrm{O}, 0.2 \mathrm{~g} ; \mathrm{CaCl}_{2}, 0.015 \mathrm{~g} ; \mathrm{FeCl}_{3}, 0.065 \mathrm{~g} ; 2 \mathrm{ml}$ of a trace element solution (Porter et al., 1983), $\mathrm{pH}$ 6.8. $\mathrm{PQQ}$ was added as indicated in the text. Lyophilized cells of $E$. coli strain W (ATCC 9637) and Azotobacter vinelandii ATCC 12518 were obtained from Sigma.

Isolation of bacteroids. $R$. leguminosarum bacteroids were isolated from the nodules of 21-d-old Pisum sativum $\mathrm{L}$. cv 'Rondo' (Cebuco, Rotterdam). Inoculation and cultivation of plants, and preparation of bacteroids were as described by Planqué \& Brussel (1979).

Measurement of aldose-dependent oxygen consumption. PQQ-dependent glucose or xylose oxidation by whole cells and bacteroids was assayed by following the rate of oxygen consumption with a Clark type oxygen electrode. Xylose was used to test the aldose dehydrogenase (GDH) activity in case cells were able to metabolize glucose through other pathways than that via GDH. The reaction was started by the addition of sugar to a final concentration of $20 \mathrm{mmol} \mathrm{l}^{-1}$. For in vivo reconstitution of GDH, cells were suspended in a potassium phosphate buffer ( $50 \mathrm{mmol} \mathrm{l}^{-1}$ ) containing $10 \mathrm{mmol} \mathrm{MgSO} \mathrm{I}^{-1}$ and preincubated for $20 \mathrm{~min}$ in the presence of $4 \mu \mathrm{M}-\mathrm{PQQ}$ unless stated otherwise. Suspensions not preincubated with $\mathrm{PQQ}$ served as a blank. In the case of experiments with lyophilized cells of $A z$. vinelandii the assay medium in addition contained $0.2 \mathrm{mmol}$ phenazine ethosulphate (PES) $1^{-1}$ to mediate electron transfer between the dehydrogenase and oxygen. All experiments were carried out at least in duplicate with two independently grown cell batches. The duplicate respiration activities never differed by more than $10 \%$.

Total organic carbon measurements. A Beckman model 915B Tocamaster total organic carbon analyser was used to determine the carbon content of whole cultures or culture supernatants, the carbon content of bacteria being obtained from the difference. Reproducibility was about $1 \%$. Bacterial dry weight was calculated assuming a carbon content of $50 \%$.

Analytical assays. Glucose was measured by the GOD-PAP method and gluconate with gluconate kinase/6phosphogluconate dehydrogenase (testkits, Boehringer Mannheim). 
Chemicals. PQQ [2,7,9-tricarboxy-1H-pyrrolo(2,3-f)quinoline-4,5-dione] was kindly provided by J.A. Duine, from the Department of Microbiology and Enzymology, Delft University of Technology. (PQQ is commercially available from Fluka.) Xylose was of the purest reagent grade and contained less than $0.02 \%$ glucose.

\section{RESULTS}

In vivo reconstitution of $G D H$ activity in $A c$. Iwoffi

Apo-GDH of $A c$. Iwoffi could be reconstituted in vivo to active GDH by addition of trace amounts of PQQ $\left(2 \mathrm{nmol} \mathrm{I}^{-1}\right)$ to the culture liquid (van Schie et al., 1984). However, washing of cells with a phosphate buffer or distilled water prior to reconstitution resulted in an almost complete loss of their ability to oxidize glucose even in the presence of $200 \mathrm{nmol} P Q Q 1^{-1}$. In contrast, washing of suspensions of holo-GDH-containing Ac. calcoaceticus in phosphate buffer had no effect on the rate of glucose oxidation in this organism (Table 1). When Ac. lwoffi was grown in standard medium in the presence of $200 \mathrm{nmol} P Q Q 1^{-1}$, washing of the suspensions with distilled water had no effect: glucose oxidation was instantaneous in the absence of PQQ (Table 1).

Both in suspensions of $A c$. calcoaceticus and in those of $A c$. lwoff glucose oxidation was accompanied by the formation of stoichiometric amounts of gluconic acid. A systematic analysis of the factors involved in the PQQ-mediated oxidation of glucose to gluconic acid in $A c$. Iwoffi revealed that $\mathrm{Ca}^{2+}$ or $\mathrm{Mg}^{2+}$ were required for reconstitution of apo-GDH with its prosthetic group PQQ. The rate of PQQ-dependent glucose oxidation by washed cells was strongly dependent on the concentration of these ions between 0.01 and $1 \mathrm{mmol} \mathrm{l}^{-1}$ (Fig. 1). Only above this concentration did the rate of glucose oxidation equal that of untreated cells. This explains the marked differences of the effects of the type of water used for the preparation of the washing buffer, since the tap water used contained $1.2 \mathrm{mmol} \mathrm{Ca}^{2+} \mathrm{I}^{-1}$ and $0.3 \mathrm{mmol} \mathrm{Mg}^{2+} \mathrm{I}^{-1}$. In the presence of excess $\mathrm{Ca}^{2+}$ or $\mathrm{Mg}^{2+}$ only nanomolar quantities of $\mathrm{PQQ}$ were required for a maximal rate of glucose oxidation (Fig. $2 a$ ). Without the addition of $\mathrm{Ca}^{2+}$ and $\mathrm{Mg}^{2+}$ reconstitution could be accomplished by addition of high concentrations $\left(10-50 \mu \mathrm{mol} \mathrm{I}^{-1}\right)$ of PQQ although activity was never more than $75 \%$ of the maximal rate (Fig $2 b$ ). Both the rate and extent of reconstitution were also affected by the $\mathrm{pH}$ of the suspension, with an optimum of $\mathrm{pH} 6.0$ (results not shown). Similar $\mathrm{Ca}^{2+}$ dependent reconstitution of apo-GDH with PQQ was found with suspensions of $E$. coli. In the presence of $4 \mathrm{mmol} \mathrm{Ca}\left(\mathrm{NO}_{3}\right)_{2} \mathrm{l}^{-1}$, only $2 \mathrm{nmol} \mathrm{PQQ} 1^{-1}$ was necessary to obtain maximal GDH activity (Fig. $2 c$ ). Washing of the reconstituted suspensions

\section{Table 1. Effect of washing of Ac. calcoaceticus or Ac. Iwoffi cells on PQQ-dependent glucose oxidation}

Cell suspensions of acetate-limited chemostat cultures $\left(0.35 \mathrm{~g} \mathrm{l}^{-1}\right)$ were centrifuged and resuspended to the same density in various media ( $\mathrm{pH} \mathrm{6.0)}$ ). In the case of $A c$. Iwoffi, the cell suspensions thus obtained were preincubated for $20 \mathrm{~min}$ with $200 \mathrm{nmol} \mathrm{PQQ} \mathrm{I}^{-1}$. Without this preincubation the rate of glucose oxidation was negligible.

\section{Washing liquid}

\begin{tabular}{|c|c|}
\hline \multicolumn{2}{|c|}{$\begin{array}{c}\text { Glucose oxidation } \\
\left.\text { [nmol } \mathrm{O}_{2} \min ^{-1}(\mathrm{mg} \text { dry } \mathrm{wt})^{-1}\right]\end{array}$} \\
\hline Ac. calcoaceticus & Ac. Iwoffi \\
\hline 170 & 0 \\
\hline 232 & 41 \\
\hline 239 & 225 \\
\hline 200 & 215 \\
\hline ND & 234 \\
\hline 213 & 191 \\
\hline
\end{tabular}

Demi* or distilled water

Potassium phosphate buffer $\left(2 \mathrm{mmol}^{-1}\right)$ in demi water Filtered culture fluid

Potassium phosphate buffer $\left(2 \mathrm{mmol}^{-1}\right)$ in tap water

Potassium phosphate buffer $\left(2 \mathrm{mmol}^{-1}\right)$ in demi water + $\mathrm{Ca}\left(\mathrm{NO}_{3}\right)_{2}\left(10 \mathrm{mmol} \mathrm{l}^{-1}\right)$

Potassium phosphate buffer $\left(2 \mathrm{mmol}^{-1}\right)$ in demi water + $\mathrm{MgSO}_{4}\left(10 \mathrm{mmol} \mathrm{l}^{-1}\right)$

* 'Demi water' is water demineralized by ion exchange chromatography ND, Not determined. 


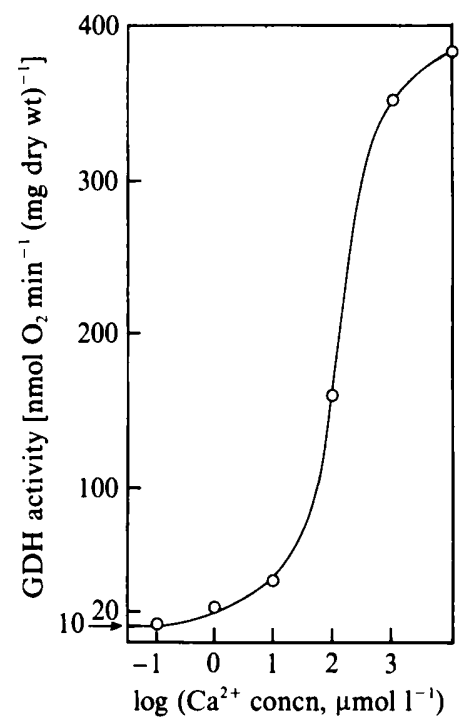

Fig. 1. Effect of $\mathrm{Ca}^{2+}$ on the specific rate of glucose-dependent oxygen consumption by $A c$. Iwoffi cells as a function of the logarithm of the $\mathrm{Ca}^{2+}$ concentration; calcium was added as $\mathrm{Ca}\left(\mathrm{NO}_{3}\right)_{2}$. Cells $(0 \cdot 3 \mathrm{~g}$ dry weight $1^{-1}$ ) obtained from an acetate limited chemostat culture were resuspended in potassium phosphate buffer ( $2 \mathrm{mmol} \mathrm{l}^{-1}, \mathrm{pH} \mathrm{6.0)}$ with $200 \mathrm{nmol}$ PQQ $\mathrm{l}^{-1}$. Cells were preincubated with the appropriate $\mathrm{Ca}^{2+}$ concentration for $20 \mathrm{~min}$ prior to addition of glucose $\left(20 \mathrm{mmol} \mathrm{l}^{-1}\right)$.

with buffer without $\mathrm{Ca}^{2+}$ and PQQ did not affect GDH activity, indicating that once the in vivo reconstitution has taken place, PQQ remains firmly bound to the enzyme.

\section{Effect of cultivation conditions on the glucose oxidizing capacity of Ac. Iwoffi}

In order to test whether the synthesis of PQQ might be inducible in $A c$. Iwoffi various cultivation conditions were examined for their effect on the capacity of cells to oxidize glucose. In all cases, however, glucose oxidation was strictly dependent on the addition of PQQ. Growth on various substrates such as malate, acetate, succinate, ethanol, histidine or peptone in batch or carbon-limited chemostat cultures and in the absence or presence of those aldose sugars which are typical substrates for GDH (glucose, xylose and ribose) did not result in sugar consumption, neither in situ nor in washed cell suspensions. Other parameters which have been shown to affect the level of active (holo) GDH in Pseudomonas spp. (Lessie \& Phibbs, 1984) and thus might have an influence on PQQ synthesis, were tested as well. Growth at a lower temperature (15 instead of $\left.30{ }^{\circ} \mathrm{C}\right)$ and variations in the dissolved oxygen tension $(50 \%$ or $300 \%$ air saturation) or culture $\mathrm{pH}(6 \cdot 0-8.0)$ had no effect on the aldose oxidizing capacity: glucose oxidation was insignificant in the absence of exogenous PQQ [i.e. less than $0.005 \mu \mathrm{mol} \mathrm{min}^{-1}(\mathrm{mg} \text { cells })^{-1}$ ] but amounted to $0 \cdot 2-0.4 \mu \mathrm{mol} \mathrm{min}^{-1}$ (mg cells) ${ }^{-1}$ in the presence of the cofactor.

\section{Apo-glucose dehydrogenase in other bacteria}

Various $E$. coli strains have also been reported to synthesize apo-GDH constitutively. As with $A c$. Iwoffi, we have not found, so far, any cultivation condition which resulted in the formation of active (holo) enzyme in $E$. coli $\mathrm{B} / \mathrm{r} / 1$. Carbon-limited chemostat cultures of this organism growing on acetate or glucose at various $\mathrm{pH}(6-8)$ and temperature $\left(15-37^{\circ} \mathrm{C}\right)$ values, at different levels of dissolved oxygen tension ( $50 \%$ or $300 \%$ air saturation) oxidized xylose only in the presence of PQQ.

In a further investigation a number of species among the Rhizobiaceae were tested for the presence of apo-GDH. For example Rhizobium leguminosarum grown in batch cultures on tryptone/yeast extract exhibited a PQQ-dependent oxidation of glucose and xylose (Table 2). 

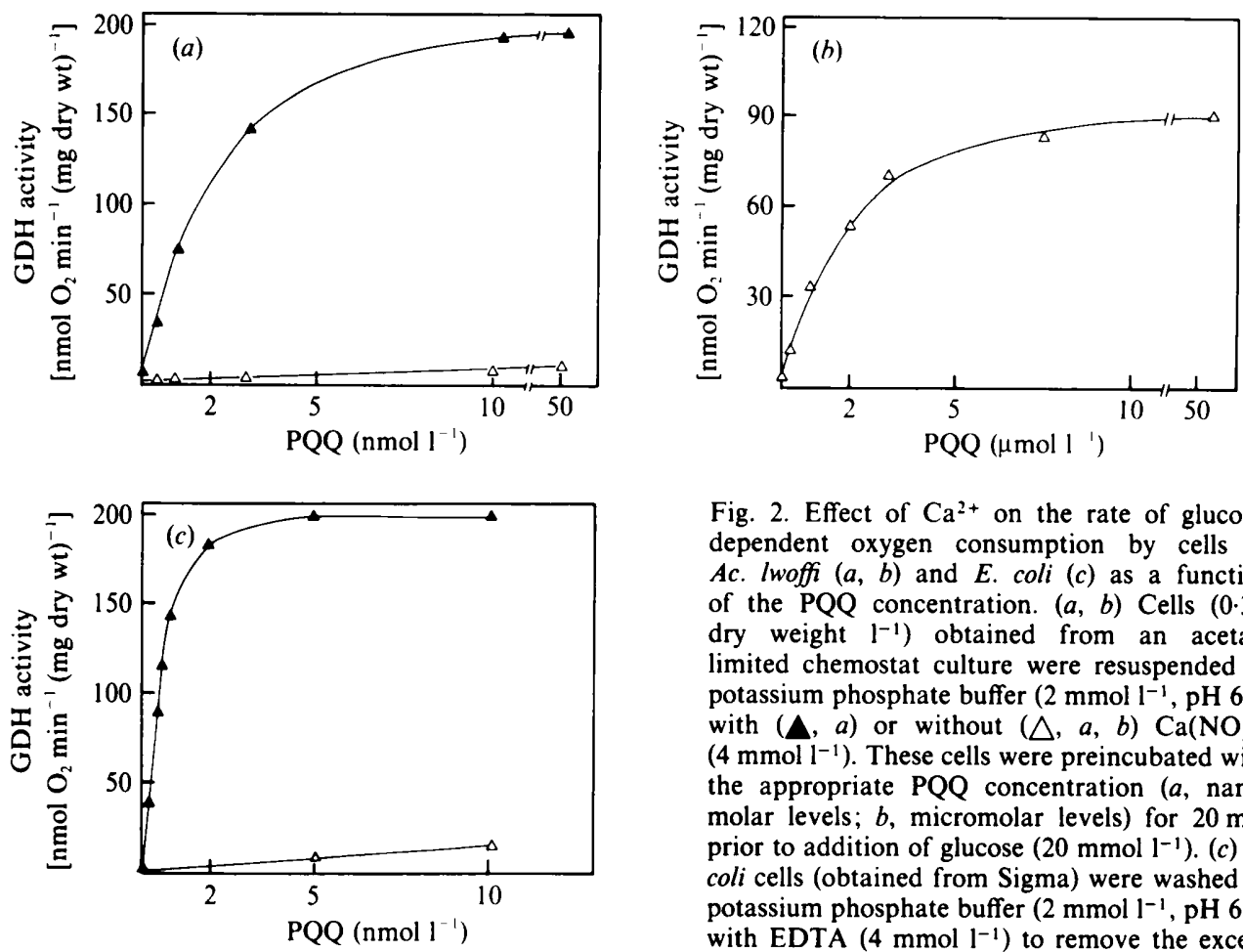

Fig. 2. Effect of $\mathrm{Ca}^{2+}$ on the rate of glucosedependent oxygen consumption by cells of $A c$. Iwoffi $(a, b)$ and $E$. coli $(c)$ as a function of the PQQ concentration. $(a, b)$ Cells $(0.3 \mathrm{~g}$ dry weight $1^{-1}$ ) obtained from an acetate limited chemostat culture were resuspended in potassium phosphate buffer $\left(2 \mathrm{mmol} \mathrm{l}^{-1}, \mathrm{pH} \mathrm{6.0}\right)$ with $(\boldsymbol{\Lambda}, a)$ or without $(\triangle, a, b) \mathrm{Ca}\left(\mathrm{NO}_{3}\right)_{2}$ $\left(4 \mathrm{mmol}^{-1}\right)$. These cells were preincubated with the appropriate PQQ concentration ( $a$, nanomolar levels; $b$, micromolar levels) for $20 \mathrm{~min}$ prior to addition of glucose $\left(20 \mathrm{mmol}^{-1}\right)$. (c) $E$. coli cells (obtained from Sigma) were washed in potassium phosphate buffer $\left(2 \mathrm{mmol} \mathrm{I}^{-1}, \mathrm{pH} \mathrm{6.0}\right)$ with EDTA $\left(4 \mathrm{mmol} \mathrm{l}^{-1}\right)$ to remove the excess $\mathrm{Ca}^{2+}$ or $\mathrm{Mg}^{2+}$ and resuspended to a final concentration of $1.6 \mathrm{~g}$ dry weight $\mathrm{l}^{-1}$ in the same buffer supplemented with $(\Lambda)$ or without $(\triangle)$ $\mathrm{Ca}\left(\mathrm{NO}_{3}\right)_{2}\left(4 \mathrm{mmol} \mathrm{l}^{-1}\right)$.

Table 2. PQQ-dependent aldose oxidation by whole cells or bacteroids of $R$. leguminosarum 248

Cells from the stationary phase of batch cultures grown on TY medium were directly assayed for PQQdependent aldose oxidation. Bacteroids were isolated as described in Methods. Measurements with the bacteroids were made in two independent preparations, $a$ and $b$.

\begin{tabular}{|c|c|c|}
\hline \multicolumn{3}{|c|}{$\begin{array}{c}\text { Oxygen consumption } \\
{\left[\text { nmoles } \min ^{-1}\left(\mathrm{mg} \mathrm{dry} \mathrm{wt}^{-1}\right]\right.}\end{array}$} \\
\hline \multirow[t]{2}{*}{ Cells } & & Bacteroids \\
\hline & $a$ & $b$ \\
\hline 4.5 & ND & ND \\
\hline $66 \cdot 3$ & ND & ND \\
\hline $5 \cdot 2$ & $4 \cdot 1$ & 0 \\
\hline 72.5 & $6 \cdot 1$ & 2.4 \\
\hline ND & $45 \cdot 0$ & 25.0 \\
\hline
\end{tabular}

ND, Not determined. 


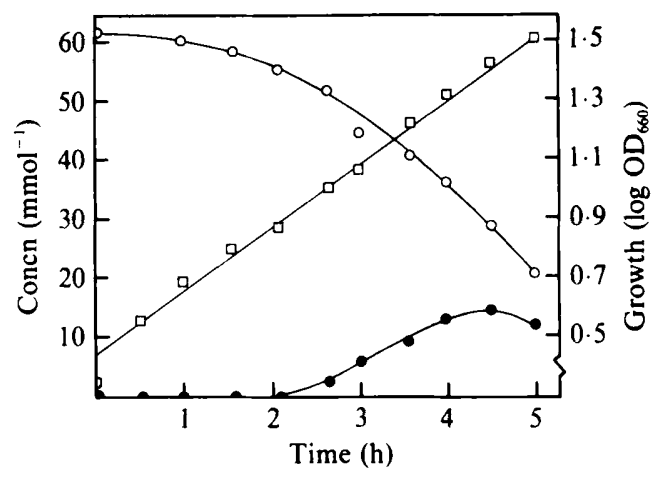

Fig. 3. PQQ-dependent glucose consumption and gluconate production by Ag. tumefaciens LBA 201. The organism was pregrown on glycerol in a carbon-limited chemostat $\mathrm{pH} 6.5$, at a cell density of $0.85 \mathrm{~g}$ dry weight $1^{-1}$. The medium supply was turned of $30 \mathrm{~min}$ before the experiment, and $\mathrm{CO}_{2}$ production from glycerol stopped immediately, indicating that glycerol was depleted. At zero time glucose was added at a final concentration of $60 \mathrm{mmol} \mathrm{l}^{-1}$. After $2 \mathrm{~h}$, PQQ (final concentration of $4 \mu \mathrm{mol} \mathrm{I}^{-1}$ ) was added to the fermenter. $\bigcirc$, Glucose; $O$, gluconate; $\square$, growth.

\section{Table 3. $P Q Q$-dependent gluconic acid production by several Gram-negative bacteria}

Organisms were grown in batch cultures as described in Methods on $10 \mathrm{~g}$ glucose $1^{-1}$ with or without 4 $\mu \mathrm{mol}$ PQQ $1^{-1}$. Gluconic acid formation was measured after depletion of glucose in the medium.

\begin{tabular}{|c|c|c|c|}
\hline Organism & PQQ & $\begin{array}{l}\mu_{\max } \\
\left(\mathrm{h}^{-1}\right)\end{array}$ & $\begin{array}{l}\text { Gluconic acid } \\
\left(\mathrm{mmol} \mathrm{l}^{-1}\right)\end{array}$ \\
\hline Agrobacterium radiobacter NCIB 11883 & - & 0.41 & 0 \\
\hline & + & 0.41 & $23 \cdot 5$ \\
\hline Agrobacterium tumefaciens C58 & - & 0.23 & 0 \\
\hline & + & 0.26 & $15 \cdot 3$ \\
\hline Pseudomonas sp. NCIB 49592 & - & 0.35 & 0.3 \\
\hline & + & 0.36 & $21 \cdot 1$ \\
\hline Rhizobium leguminosarum 248 & - & 0.096 & 0 \\
\hline
\end{tabular}

High concentrations of gluconic acid were found in cultures of $R$. leguminosarum grown in the presence of PQQ (Table 3). The presence of apo-GDH in two other Rhizobium species, $R$. leguminosarum biovar trifolii and $R$. meliloti, grown on tryptone/yeast extract, was evident from the PQQ-dependent glucose and xylose oxidation (results not shown). The influence of cultivation conditions on the synthesis of apo-GDH in these organisms has not yet been systematically investigated. However, in bacteroids of $R$. leguminosarum isolated from root nodules of Pisum sativum the rate of PQQ-dependent aldose oxidation was very low compared to that of free-living cells (Table 2).

Various Agrobacterium strains were also found to synthesize apo-GDH. Apo-enzyme was detected in Ag. radiobacter (NCIB 11883) and Ag. tumefaciens LBA 201 when grown in batch cultures (Table 3). Production of gluconic acid accounted for up to $40 \%$ of the initial amount of glucose and did not significantly influence the growth rate. Similarly, when glucose was added to cells of Ag. tumefaciens LBA 201 pregrown in a glycerol-limited chemostat, gluconic acid was produced instantaneously after the addition of PQQ (Fig. 3). Again, the growth rate did not change during the production of gluconic acid.

The in vivo activity of apo-GDH as visualized by PQQ-dependent gluconic acid production was quite stable. Cells of $\mathrm{Ag}$. tumefaciens LBA 201 starved for 2 weeks in mineral medium without carbon source still showed PQQ dependent formation of gluconic acid from glucose (results not shown). Suspensions of lyophilized cells of Az. vinelandii (ATCC 12518) obtained from a commercial source also exhibited PQQ-dependent oxidation of xylose, in the presence of 
PES (to optimize electron transfer from the GDH to oxygen), of $70 \mathrm{nmol}$ xylose oxidized $\mathrm{min}^{-1}$ (mg cells) $)^{-1}$.

Non-coordinated synthesis of PQQ and apo-GDH protein has been reported to occur in Pseudomonas aeruginosa during anaerobic growth on glucose with nitrate (van Schie et al., 1984). Table 3 shows that also in aerobic cultures of Pseudomonas sp. NCIB 49592, substantial apoGDH can be demonstrated in addition to holo-GDH.

In view of their taxonomic relationship to the genus Pseudomonas, various Xanthomonas strains (see Methods) were tested for the presence of apo-GDH. However, all strains tested failed to catalyse PQQ dependent gluconate production, suggesting the absence of apo-GDH in this genus.

\section{DISCUSSION}

The recent finding (van Schie et al., 1984, 1985; Hommes et al., 1984) that organisms such as $A c$. Iwoffi and $E$. coli contain exclusively apo-enzyme GDH, and no holo-enzyme activity, has prompted the investigation of various aspects of this phenomenon in more detail. The present study has shown that asynchronous or even independent synthesis of apo-GDH and its coenzyme PQQ can be found in strains of $A c$. lwoffi and $E$. coli, and also in Pseudomonas, Azotobacter, Rhizobium and Agrobacterium species. Thus, the 'cryptic' presence of GDH is widespread in nature. The amounts of PQQ required for the reconstitution of GDH under optimal conditions are in the nanomolar range and it may well be that such concentrations are available in the environment since a number of bacteria excrete micromolar quantities of $P Q Q$ (Ameyama et al., 1984a; Duine et al., 1985). The possibility that PQQ might, in fact, be considered as a vitamin (van Schie et al., 1984) is supported by the recent observation (Shimao et al., 1986) that polyvinyl degrading Pseudomonas spp. require PQQ for growth on this compound.

An important experimental aspect of the in vivo reconstitution of GDH is the requirement for $\mathrm{Ca}^{2+}$ or $\mathrm{Mg}^{2+}$. In the presence of $\mathrm{Ca}^{2+}$, only $2 \mathrm{nmol} \mathrm{PQQ}^{-1}$ was necessary for the reconstitution of GDH in both $A c$. Iwoffi and $E$. coli strain W, whereas micromolar quantities were required in its absence (Fig 2). Experiments with washed bacteria containing either native holo-GDH or reconstituted GDH showed that once active GDH is present, these cations are no longer needed. These observations show that earlier reports on the stimulatory effect of $\mathrm{Ca}^{2+} \mathrm{or}^{\mathrm{Mg}^{2+}}$ on dyelinked glucose oxidation (Dalby \& Blackwood, 1955; Hauge, 1961) and on the reconstitution of GDH activity (Ameyama et al., 1985) in cell-free extracts are also relevant for the in vivo situation.

In view of the very low amounts of PQQ required for the reconstitution of GDH, glassware or media contaminated with traces of $P Q Q$ might produce false positive tests for the presence of holo-GDH in a culture (PQQ is very stable and tends to stick to glass: M.A.G. van Kleef, P. Dokter \& J.A. Duine, personal communication). In addition, it is possible that deionized water might be contaminated with PQQ, as ion exchange resins often contain hyphomicrobia (J.B.M. Meiberg \& W. Harder, personal communication) which produce and excrete PQQ. Hyphomicrobium spp. are also well-known inhabitants of water pipes (Harder \& Attwood, 1978) and therefore tap water may also contain PQQ. Recently it has been reported that E. coli K12, and $A g$. radiobacter, grown in media prepared with tap water contained low holo-GDH activity (Ameyama et al., 1985), and that another $E$. coli strain excreted low amounts of PQQ (0.2 nmol $1^{-1}$ ) into the growth medium (Ameyama et al., 1984b). It is our experience that the presence of low GDH activity in, for example E. coli, can be traced back to scavenging of the cofactor from the medium rather than from biosynthesis. Unequivocal evidence for PQQ production requires the demonstration of an increase in the total PQQ present in a closed system as a function of metabolic activity at various time intervals. Thus far, this remains to be demonstrated for $A c$. Iwoffi and E. coli.

In Pseudomonas spp. the activity of GDH may be regulated by the synthesis of PQQ (Table 3, van Schie et al., 1984). It thus remained possible that species such as $A c$. Iwoffi and E. coli which synthesize apo-enzyme exclusively might synthesize $\mathrm{PQQ}$ under unknown growth conditions. Both organisms were therefore grown under conditions which might favour PQQ synthesis, such 
as energy stress (van Schie et al., 1985) and high temperature or osmotic values (Lessie \& Phibbs, 1984). All attempts to detect PQQ synthesis have failed and therefore the possibility that PQQ is a vitamin seems the most logical alternative.

Even if $\mathrm{PQQ}$ was available to the organism as a vitamin, its physiological function is only partially understood. In organisms such as Acinetobacter spp. and $E$. coli GDH may play a role in energy metabolism, for example as an (auxiliary) energy generating system (van Schie et al., 1985).

The role of GDH in the Rhizobium and Agrobacterium species tested is not understood. It is known that in the Rhizobiaceae glucose can be metabolized through the Entner-Doudoroff and pentose phosphate pathways (Arthur et al., 1973; Glenn et al., 1984), but the direct oxidation pathway was considered to be absent (Vardanis et al., 1961; Glenn et al., 1984). However there are clear indications for a direct oxidation of L-arabinose (Pedrosa \& Zancan, 1974; Duncan, 1979) and for direct oxidation of glucose to 2-ketogluconic acid (Courtois et al., 1979). As this probably proceeds via the production of gluconate by GDH, it is an indication that Rhizobium species may sometimes contain active GDH. These data, combined with the finding by Trinchant et al. (1981) that bacteroids may show glucose-dependent nitrogenase activity in vitro, and our observation that bacteroids of $R$. leguminosarum possess low but significant GDH activities, provide a basis for a reinvestigation of the glucose metabolism in Rhizobiaceae.

We would like to thank the following persons with whom we had several stimulating discussions: Professor Dr R. A. Schilperoort, Professor Dr K. R. Libbenga, Professor Dr E. J. J. Lugtenberg, Professor Dr A. Quispel, and Dr A. A. N. van Brussel. We are indebted to Dr J. W. Kijne for the supply of pea plants, to Dr R. J. Rouwenhorst who performed some of the experimental work and to Lesley Robertson for critical reading of the manuscript.

\section{REFERENCES}

Ameyama, M., Hayashi, M., Matsushita, K., SinAGaWA, E. \& AdACHI, O. (1984a). Microbial production of pyrrolo-quinoline quinone. Agricultural and Biological Chemistry 48, 561-565.

Ameyama, M., Sinagawa, E., Matsushita, K. \& ADACHI, O. (1984b). Growth stimulating substance for microorganisms produced by Escherichia coli causing the reduction of the lag phase in microbial growth and identity of the substance with pyrroloquinoline quinone. Agricultural and Biological Chemistry 48, 3099-3107.

ameyama, M., Nonobe M., Hayashi, M., Sinagawa, E., Matsushita, K., \& Adachi, O. (1985). Mode of binding of pyrroloquinoline quinone to apo-glucose dehydrogenase. Agricultural and Biological Chemistry 49, 1227-1231.

Arthur, L. O., Bulla, L. A., JR, Julian, G. \& NaKamura, L. K. (1973). Carbohydrate metabolism in Agrobacterium tumefaciens. Journal of Bacteriology 116, 304-313.

Beardmore-Gray, M. \& ANTHONy, C. (1986). The oxidation of glucose by Acinetobacter calcoaceticus: the interaction of the quinoprotein glucose dehydrogenase with the electron transport chain. Journal of General Microbiology 132, 1257-1268.

Courtois, B., Hornezet, J. P. \& Derieux, J. C. (1979). Effet de la synthèse d'acide 2 céto-gluconique sur la production d'exopolysaccharides par une souche de Rhizobium meliloti. Canadian Journal of Microbiology 25, 1191-1196.

Dalby, A. \& BlaCKWOOD, A. C. (1955). Oxidation of sugars by an enzyme preparation from Aerobacter

aerogenes. Canadian Journal of Microbiology 1, 733742.

Dawes, E. A. (1981). Carbon metabolism. In Continuous Culture of Cells, vol 2, pp. 1-38. Edited by P.H. Calcott. Boca Raton, Florida: CRC Press.

DOELLE, H. W. (1975). Bacterial metabolism, pp. 274 278. London: Academic Press.

Duine, J. A., Frank, J., JZN \& Zeeland, J. K. (1979). Glucose dehydrogenase from Acinetobacter calcoaceticus: a quinoprotein. FEBS Letters 108, 443-446.

Duine, J. A., Frank, J., JZn \& Jongejan, J. A. (1985). The coenzyme PQQ and quinoproteins, a novel class of oxidoreductase enzymes. In Proceedings of the 16th FEBS Congress, part A, pp. 79-88. Utrecht: VNU Science Press.

Duncan, M. J. (1979). L-Arabinose metabolism in rhizobia. Journal of General Microbiology 113, 177179.

Glenn, A. R., McKay, I. A., Arwas, R. \& DilWORTH, M. J. (1984). Sugar metabolism and the symbiotic properties of carbohydrate mutants of Rhizobium leguminosarum. Journal of General Microbiology 130, 239-245.

Groen, B. W., van Kleef, M. A. G. \& Duine, J. A. (1986). Quinohaemoprotein alcohol dehydrogenase apoenzyme from Pseudomonas testosteroni. Biochemical Journal 234, 611-615.

HARDER, W. \& ATTWOOD, M. M. (1978). Biology, physiology, biochemistry of hyphomicrobia. Advances in Microbial Physiology 17, 308-356.

Hauge, J. G. (1960). Purification and properties of glucose dehydrogenase and cytochrome $b$ from 
Bacterium anitratum. Biochimica et biophysica acta 45, 250-262.

Hauge, J. G. (1961). Glucose dehydrogenase in bacteria: a comparative study. Journal of Bacteriology 82, 609-614.

Hommes, R. W. J., Postma, P. W., Neijssel, O. M., Tempest, D. W., DoKter, P. \& Duine, J. A. (1984). Evidence of quinoprotein glucose dehydrogenase apoenzyme in several strains of Escherichia coli. FEMS Microbiology Leitters 24, 329-333.

JUNI, E. (1978). Genetics and physiology of Acinetobacter. Annual Review of Microbiology 32, 349-371.

Lessie, T. G. \& PhibBs, P. V. (1984). Alternative pathways of carbohydrate utilization in Pseudomonas. Annual Review of Microbiology 38, 358-387.

Pedrosa, F. O. \& Zancan, G. T. (1974). L-Arabinose metabolism in Rhizobium japonicum. Journal of Bacteriology 119, 336-338.

Planqué, K. \& Van Brussel, A. A. N. (1979). An improved large-scale isolation procedure for bacteroids of Rhizobium leguminosarum Frank from Pisum sativum L. Plant and Soil 45, 309-315.

PORTER, N., Drozd, J. W. \& LiNTon, J. D. (1983). The effects of cyanide on the growth and respiration of Enterobacter aerogenes in continuous culture. Journal of General Microbiology 129, 7-16.

Pronk, J. T., van Schie, B. J., van DiJken, J. P. \& KUENEN, J. G. (1986). Energization of solute transport by $\mathrm{PQQ}$-dependent glucose dehydrogenase in membrane vesicles of Acinetobacter species. Antonie van Leeuwenhoek 51, 560-561.

van Schie, B. J., van Dijken, J. P. \& Kuenen, J. G. (1984). Non-coordinated synthesis of glucose dehydrogenase and its prosthetic group PQQ in Acineto- bacter and Pseudomonas species. FEMS Microbiology Letters 24, 133-138.

van Schie B. J., Hellingwerf, K. J., van Dijken, J. P., Elferink, M. G. L., VAN DiJl, J. M., Kuenen, J. G. \& Konings, W. N. (1985). Energy transduction by electron transfer via a pyrrolo-quinoline quinone dependent glucose dehydrogenase in Escherichia coli, Pseudomonas aeruginosa and Acinetobacter calcoaceticus (var. Iwoffi). Journal of Bacteriology 136, 493-499.

Shimao, M., Ninomiya, K., Kuno, O., Kato, N. \& SaKazawa, C. (1986). Existence of a novel enzyme, pyrroloquinoline quinone-dependent polyvinyl alcohol dehydrogenase, in a bacterial symbiont, Pseudomonas sp. strain VM15C. Applied and Environmental Microbiology 51, 268-275.

Trinchant, J. C., Birot, A. M. \& Rigaud, J. (1981). Oxygen supply and energy-yielding substrates for nitrogen fixation (acetylene reduction) by bacteroid preparations. Journal of General Microbiology 125, 159-165.

VARDANIS, A. \& Hochster, R. M. (1961). On the mechanism of glucose metabolism in the plant tumor-inducing organism Agrobacterium tumefaciens. Canadian Journal of Biochemistry and Physiology 39, 1165-1182.

DE VRIES, G. E. (1980). Transport of sugars and organic acids in Rhizobium leguminosarum and their role in symbiosis. PhD thesis, University of Leiden.

Zambryski, P., JoOS, H., LeEmans, J., Van Montagu, M. \& SChell, J. (1983). Ti plasmid vector for the introduction of DNA into plant cells without alteration of their normal regeneration capacity. EMBO Journal 2, 2143-2150. 